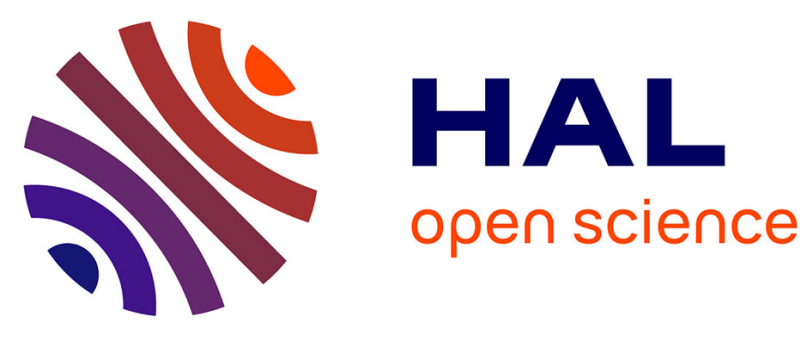

\title{
Telmisartan to prevent recurrent stroke and cardiovascular events.
}

\author{
Salim Yusuf, Hans-Christoph Diener, Ralph L Sacco, Daniel Cotton, \\ Stephanie Ounpuu, William A Lawton, Yuko Palesch, Reneé H Martin, \\ Gregory W Albers, Philip Bath, et al.
}

\section{To cite this version:}

Salim Yusuf, Hans-Christoph Diener, Ralph L Sacco, Daniel Cotton, Stephanie Ounpuu, et al.. Telmisartan to prevent recurrent stroke and cardiovascular events.. New England Journal of Medicine, 2008, 359 (12), pp.1225-37. 10.1056/NEJMoa0804593 . hal-00626465

\section{HAL Id: hal-00626465 \\ https://hal-unilim.archives-ouvertes.fr/hal-00626465}

Submitted on 11 Jun 2021

HAL is a multi-disciplinary open access archive for the deposit and dissemination of scientific research documents, whether they are published or not. The documents may come from teaching and research institutions in France or abroad, or from public or private research centers.
L'archive ouverte pluridisciplinaire HAL, est destinée au dépôt et à la diffusion de documents scientifiques de niveau recherche, publiés ou non, émanant des établissements d'enseignement et de recherche français ou étrangers, des laboratoires publics ou privés. 
ORIGINAL ARTICLE

\section{Telmisartan to Prevent Recurrent Stroke and Cardiovascular Events}

\author{
Salim Yusuf, M.B., B.S., D.Phil., Hans-Christoph Diener, M.D., Ph.D., \\ Ralph L. Sacco, M.D., Daniel Cotton, M.S., Stephanie Ônpuu, Ph.D., \\ William A. Lawton, B.A., Yuko Palesch, Ph.D., Reneé H. Martin, Ph.D., \\ Gregory W. Albers, M.D., Philip Bath, F.R.C.P., Natan Bornstein, M.D., \\ Bernard P.L. Chan, M.D., Sien-Tsong Chen, M.D., Luis Cunha, M.D., Ph.D., \\ Björn Dahlöf, M.D., Ph.D., Jacques De Keyser, M.D., Ph.D., \\ Geoffrey A. Donnan, M.D., Conrado Estol, M.D., Ph.D., Philip Gorelick, M.D., \\ Vivian Gu, M.D., Karin Hermansson, D.M.Sc., Lutz Hilbrich, M.D., \\ Markku Kaste, M.D., Ph.D., Chuanzhen Lu, M.D., Thomas Machnig, M.D., \\ Prem Pais, M.D., Robin Roberts, M.Tech., Veronika Skvortsova, M.D., Philip Teal, M.D., \\ Danilo Toni, M.D., Cam VanderMaelen, Ph.D., Thor Voigt, M.D., Michael Weber, M.D., \\ and Byung-Woo Yoon, M.D., Ph.D., for the PRoFESS Study Group**
}

\section{A B STRACT}

\section{BACKGROUND}

Prolonged lowering of blood pressure after a stroke reduces the risk of recurrent stroke. In addition, inhibition of the renin-angiotensin system in high-risk patients reduces the rate of subsequent cardiovascular events, including stroke. However, the effect of lowering of blood pressure with a renin-angiotensin system inhibitor soon after a stroke has not been clearly established. We evaluated the effects of therapy with an angiotensin-receptor blocker, telmisartan, initiated early after a stroke.

\section{METHODS}

In a multicenter trial involving 20,332 patients who recently had an ischemic stroke, we randomly assigned 10,146 to receive telmisartan ( $80 \mathrm{mg}$ daily) and 10,186 to receive placebo. The primary outcome was recurrent stroke. Secondary outcomes were major cardiovascular events (death from cardiovascular causes, recurrent stroke, myocardial infarction, or new or worsening heart failure) and new-onset diabetes.

\section{RESULTS}

The median interval from stroke to randomization was 15 days. During a mean followup of 2.5 years, the mean blood pressure was $3.8 / 2.0 \mathrm{~mm} \mathrm{Hg}$ lower in the telmisartan group than in the placebo group. A total of 880 patients $(8.7 \%)$ in the telmisartan group and 934 patients $(9.2 \%)$ in the placebo group had a subsequent stroke (hazard ratio in the telmisartan group, 0.95 ; $95 \%$ confidence interval [CI], 0.86 to $1.04 ; \mathrm{P}=0.23$ ). Major cardiovascular events occurred in 1367 patients (13.5\%) in the telmisartan group and 1463 patients (14.4\%) in the placebo group (hazard ratio, 0.94; 95\% CI, 0.87 to 1.01; $\mathrm{P}=0.11$ ). New-onset diabetes occurred in $1.7 \%$ of the telmisartan group and $2.1 \%$ of the placebo group (hazard ratio, $0.82 ; 95 \% \mathrm{CI}, 0.65$ to $1.04 ; \mathrm{P}=0.10$ ).

\section{CONCLUSIONS}

Therapy with telmisartan initiated soon after an ischemic stroke and continued for 2.5 years did not significantly lower the rate of recurrent stroke, major cardiovascular events, or diabetes. (ClinicalTrials.gov number, NCT00153062.)
The authors' affiliations are listed in the Appendix. Address reprint requests to Dr. Yusuf at the Population Health Research Institute, Hamilton Health Sciences and McMaster University, 237 Barton St. East, Hamilton, ON L8L 2X2, Canada, or atyusufs@mcmaster.ca.

Drs. Yusuf, Diener, and Sacco contributed equally to this article.

*Investigators in the Prevention Regimen for Effectively Avoiding Second Strokes (PRoFESS) Study Group are listed in the Appendix.

This article (10.1056/NEJMoa0804593) was published at www.nejm.org on August 27, 2008.

N EnglJ Med 2008;359

Copyright $\odot 2008$ Massachusetts Medical Society. 
TROKE IS THE SECOND MOST FREQUENT cause of death in the world and is responsible for about 5 million deaths each year. ${ }^{1}$ An additional 15 million persons have nonfatal strokes, with about a third having disabling consequences. Elevated blood pressure is the strongest risk factor for stroke, and lowering of blood pressure, especially in patients with substantially elevated levels (e.g., systolic pressure, >160 mm Hg), reduces the risk of stroke. ${ }^{2}$ After a stroke, lowering blood pressure with a combination of an angiotensin-converting-enzyme (ACE) inhibitor and a diuretic reduced rates of recurrent stroke in the Perindopril Protection against Recurrent Stroke Study (PROGRESS). ${ }^{3}$

Several other trials have raised the possibility of an additional mechanism, independent of blood-pressure lowering, by which blockers of the renin-angiotensin system may be beneficial in patients with stroke. ${ }^{4}$ In the Heart Outcomes Prevention Evaluation (HOPE) trial, ACE-inhibitor therapy reduced the rate of stroke in patients with previous cardiovascular events or high-risk diabetes despite only a small reduction in blood pressure, with consistent results in those with and those without previous strokes.5,6 Another recent trial $^{7}$ demonstrated that eprosartan reduced the number of recurrent strokes and transient ischemic attacks (but not the proportion of patients with stroke), as compared with a calciumchannel blocker, in patients with previous stroke, despite a similar reduction in blood pressure. In one small study, an angiotensin-receptor blocker (ARB) that was started soon after a stroke reduced the rates of death and cardiovascular events despite no blood-pressure reduction. ${ }^{8}$

In these studies, the majority of patients were enrolled several months or years after a stroke, and the potential benefit of the use of reninangiotensin system blockers soon after a stroke was not clearly established. We therefore evaluated whether therapy with telmisartan, an ARB, given at a dose of $80 \mathrm{mg}$ per day, could reduce the risk of stroke when initiated within 4 months after a stroke and continued for 2.5 years.

\section{METHODS}

STUDY PROTOCOL

Details of the trial protocol have been published previously. ${ }^{9}$ Patients were from 695 centers in 35 countries and had recently had an ischemic stroke. We used a two-by-two factorial design to compare four regimens: a combination of acetylsalicylic acid (aspirin) and extended-release dipyridamole, as compared with clopidogrel, and telmisartan as compared with placebo. All patients also received medications for blood-pressure control at the discretion of the investigators. The trial was approved by the ethics committee or institutional review board at each national or local site. This report focuses on the component of the trial comparing telmisartan with placebo.

\section{STUDY DESIGN}

The trial was sponsored by Boehringer Ingelheim, with additional support from Bayer Schering Pharma and GlaxoSmithKline, and was designed by the steering committee, which included representatives of the sponsor. Data were collected by investigators at each site. The final statistical analyses were conducted simultaneously by independent statisticians at the Medical University of South Carolina, who provided data and interim analysis reports to the data and safety monitoring committee, and the statisticians from Boehringer Ingelheim. After the database was locked, a confirmatory analysis was performed by the sponsor. Minor discrepancies between the two data analyses were resolved by mutual agreement. The three principal academic investigators had full access to the data, wrote the manuscript with input from all the coauthors, and vouch for the accuracy and completeness of the data and the analyses.

\section{ELIGIBILITY}

According to the initial protocol, patients 55 years of age or older who had had an ischemic stroke less than 90 days before randomization and whose condition was stable were eligible to participate in the study. The diagnosis of ischemic stroke was defined as a new focal neurologic deficit of cardiovascular origin persisting for more than 24 hours. Patients whose symptoms persisted for less than 24 hours could be included if they had evidence of a recent ischemic stroke on computed tomography or magnetic resonance imaging. After about 6000 patients had been enrolled, the protocol was modified to allow the inclusion of younger patients (50 to 54 years) and those who had had less recent strokes (within 90 to 120 days) if they also had at least two additional risk 
factors. Patients were excluded if they had had a primary hemorrhagic stroke, severe disability after the qualifying stroke, contraindications to one of the study antiplatelet agents, or other factors making them unsuitable for randomization. ${ }^{9}$ All participants provided written informed consent.

\section{RANDOMIZATION, TREATMENT, AND FOLLOW-UP}

Eligible and consenting patients underwent randomization with the use of a central telephone system to receive either a twice-daily fixed-dose combination of aspirin ( $25 \mathrm{mg}$ ) plus extendedrelease dipyridamole (200 $\mathrm{mg}$ ) or once-daily clopidogrel $(75 \mathrm{mg})$ and either once-daily telmisartan $(80 \mathrm{mg}$ ) or placebo. Patients were evaluated at the time of hospital discharge or in a clinic visit at 1 week and then at 1, 3, and 6 months; they were then evaluated every 6 months. Interim telephone calls were scheduled halfway between clinic visits.

\section{OUTCOME EVENTS}

The primary outcome was recurrent stroke of any type. The two secondary outcomes were major cardiovascular events (death from cardiovascular causes, myocardial infarction, recurrent stroke, or worsening or new heart failure) and new-onset diabetes. A central committee adjudicated the primary outcome and the first of the secondary outcomes, whereas the diagnosis of new-onset diabetes was based on center reports.

\section{STATISTICAL ANALYSIS}

The trial was initially designed to enroll 15,500 patients, a sample size that was considered sufficient to accrue 2170 patients with recurrent stroke during a 4-year trial. On the basis of this assumption, the trial would have a power of more than $99 \%$ to detect a relative risk reduction of $25 \%$ in the telmisartan group, as compared with the placebo group, given the evidence at the time. ${ }^{6,10}$ However, despite a subsequent increase in sample size to more than 20,000 patients and a 6-month extension of the trial, only 1715 patients with recurrent stroke were projected. This revised event rate provided a power of $91 \%$ to detect a relative risk reduction of $15 \%$ in the telmisartan group, as compared with the placebo group.

The primary analysis was the time to recurrent stroke. A Cox proportional-hazards regres- sion model with baseline age, diabetes status, ACE-inhibitor use, and modified Rankin Scale as covariates was the prespecified model intended to be used for the analysis of outcomes. However, the assumption of proportional hazards was not satisfied, and we therefore explored whether the treatment effect varied according to time (after an inspection of the Kaplan-Meier curves), with additional analyses describing the results separately within and beyond 6 months. All analyses of the outcomes were conducted under the intention-totreat principle with the use of a time-to-event approach and included all randomized patients.

Subgroup analyses for the primary outcome and for major cardiovascular events were evaluated with the use of tests for interaction for prespecified baseline features. These included the use of ACE inhibitors, systolic blood pressure, history of diabetes mellitus, and a stroke risk score generated from the overall data of the trial, which included age, sex, physical activity level, baseline systolic blood pressure, history of hypertension, diabetes status, previous myocardial infarction, atrial fibrillation, peripheral arterial disease, and stroke before qualifying event (for details, see the Supplementary Appendix, available with the full text of this article at www.nejm.org).

\section{RESULTS}

\section{PATIENTS}

From September 11, 2003, to July 14, 2006, a total of 20,332 patients were enrolled in the trial. Of these patients, 10,146 were assigned to receive telmisartan and 10,186 to receive placebo. Baseline characteristics of the patients are shown in Table 1 . The mean blood pressure at entry was $144.1 \mathrm{~mm} \mathrm{Hg}$ systolic and $83.8 \mathrm{~mm} \mathrm{Hg}$ diastolic. About $42 \%$ of the patients had an ethnic background other than white European, 25\% had had previous transient ischemic attacks (TIA) or stroke before the qualifying stroke, $19 \%$ had evidence of atherosclerosis in other vascular beds, $28 \%$ had diabetes, $74 \%$ had a history of hypertension, and $57 \%$ were current or previous smokers; $37 \%$ of patients were receiving an ACE inhibitor. The majority of patients had recently had a qualifying stroke caused by occlusion of a small artery, and $24 \%$ were at least moderately disabled (score on Rankin Scale, $\geq 3$ ). The time from stroke to randomization was 10 days or less among 8087 pa- 
tients (40\%), 11 to 30 days among 5887 patients (29\%), and more than 30 days among $6314 \mathrm{pa}-$ tients (31\%). The median interval from stroke to randomization was 15 days.

\section{FOLLOW-UP AND ADHERENCE}

The mean duration of follow-up was 30 months (range, 18 to 52). A total of 125 patients (51 in the telmisartan group and 74 in the placebo group) $(0.6 \%)$ were lost to follow up.

Among patients in the telmisartan group, 7627 of 9825 patients $(77.6 \%)$ were receiving the study drug at 1 year, 5453 of 7403 (73.7\%) at 2 years, and 1736 of $2542(68.3 \%)$ at 3 years, with 175 (1.7\%) receiving a nonstudy ARB at 1 year and $233(2.3 \%)$ at the penultimate visit. In the placebo group, 7916 of 9856 patients (80.3\%) were receiving a study drug at 1 year, 5702 of 7439 (76.7\%) at 2 years, and 1803 of 2545 (70.8\%) at 3 years, with $219(2.2 \%)$ receiving a nonstudy ARB at 1 year and $254(2.5 \%)$ at the penultimate visit.

By the end of the study, the use of diuretics, ACE inhibitors, calcium-channel blockers, and beta-blockers was more frequent in the placebo group than in the telmisartan group, with the comparative rates as follows: diuretics, $22.6 \%$ in

\begin{tabular}{|c|c|c|}
\hline Variable & Telmisartan $(N=10,146)$ & Placebo $(\mathrm{N}=10,186)$ \\
\hline Age $-y r$ & $66.1 \pm 8.6$ & $66.2 \pm 8.6$ \\
\hline Blood pressure $-\mathrm{mm} \mathrm{Hg}$ & $144.1 \pm 16.4 / 83.8 \pm 10.5$ & $144.2 \pm 16.7 / 83.8 \pm 10.6$ \\
\hline Heart rate - beats/min & $73.2 \pm 11.7$ & $73.1 \pm 11.7$ \\
\hline Body-mass index & $26.8 \pm 5.0$ & $26.8 \pm 5.0$ \\
\hline Female sex - no. (\%) & $3619(35.7)$ & $3691(36.2)$ \\
\hline \multicolumn{3}{|l|}{ Ethnic group — no. (\%)† } \\
\hline Chinese & $1843(18.2)$ & $1823(17.9)$ \\
\hline South Asian & $849(8.4)$ & $863(8.5)$ \\
\hline Other Asian & $640(6.3)$ & $642(6.3)$ \\
\hline African & $407(4.0)$ & $409(4.0)$ \\
\hline White/European & $5827(57.4)$ & $5870(57.6)$ \\
\hline Native Latin & $494(4.9)$ & $496(4.9)$ \\
\hline Other & $86(0.8)$ & $83(0.8)$ \\
\hline \multicolumn{3}{|l|}{ Clinical history — no. (\%) } \\
\hline Previous stroke or TIA & $2486(24.5)$ & $2511(24.7)$ \\
\hline Atherosclerotic disease & $1898(18.7)$ & $2053(20.2)$ \\
\hline Atrial fibrillation & $266(2.6)$ & $274(2.7)$ \\
\hline Hypertension & $7510(74.0)$ & $7538(74.0)$ \\
\hline Diabetes mellitus & $2840(28.0)$ & $2903(28.5)$ \\
\hline Hyperlipidemia & $4735(46.7)$ & $4758(46.7)$ \\
\hline Left ventricular hypertrophy & $1577(15.5)$ & $1590(15.6)$ \\
\hline \multicolumn{3}{|l|}{ Smoking status - no. (\%) } \\
\hline Current & $2151(21.2)$ & $2157(21.2)$ \\
\hline Past & $3703(36.5)$ & $3649(35.8)$ \\
\hline \multicolumn{3}{|l|}{ Use of medication at baseline - no. (\%) } \\
\hline Statin & $4742(46.7)$ & $4872(47.8)$ \\
\hline ACE inhibitor & $3737(36.8)$ & $3782(37.1)$ \\
\hline Diuretic & $2093(20.6)$ & $2168(21.3)$ \\
\hline Calcium-channel blocker & $2487(24.5)$ & $2473(24.3)$ \\
\hline Beta-blocker & $2096(20.7)$ & $2135(21.0)$ \\
\hline Index stroke $\leq 10$ days before randomization - no. (\%) & $4021(39.6)$ & $4066(39.9)$ \\
\hline
\end{tabular}




\begin{tabular}{|lcc|}
\hline Table 1. (Continued.) & & \\
\hline Variable & Telmisartan $(\mathbf{N}=10,146)$ & Placebo $(\mathbf{N}=\mathbf{1 0 , 1 8 6 )}$ \\
TOAST classification & & \\
$\quad$ Large-artery atherosclerosis & $2907(28.7)$ & $2898(28.5)$ \\
Cardioembolism & $187(1.8)$ & $182(1.8)$ \\
Small-artery occlusion & $5283(52.1)$ & $5295(52.0)$ \\
Other & $1769(17.4)$ & $1811(17.8)$ \\
Score on modified Rankin Scale - no. (\%)) & & $1433(14.1)$ \\
0 & $1420(14.0)$ & $3848(37.8)$ \\
1 & $3732(36.8)$ & $2526(24.8)$ \\
2 & $2555(25.2)$ & $2379(23.4)$ \\
$3-5$ & $2439(24.0)$ & \\
Baseline NIH Stroke Scale - no. (\%) 9 & & $4047(39.7)$ \\
$0-1$ & $4044(39.9)$ & $3049(29.9)$ \\
$2-3$ & $2937(28.9)$ & $1612(15.8)$ \\
$4-5$ & $1740(17.1)$ & $1397(13.7)$ \\
$6-14$ & $1350(13.3)$ & $79(0.8)$ \\
$>14$ & $72(0.7)$ &
\end{tabular}

* Plus-minus values are means \pm SD. The body-mass index is the weight in kilograms divided by the square of the height in meters. ACE denotes angiotensin-converting enzyme, NIH National Institutes of Health, TIA transient ischemic attack, and TOAST Trial of ORG 10172 in Acute Stroke Treatment.

$\dagger$ Ethnic group was self-reported. The term Native Latin refers to Latin American ethnic background. $+\mathrm{P}=0.05$.

$\int$ The modified Rankin Scale score ranges from 0 to 6 , with higher scores indicating greater severity.

I The NIH Stroke Scale ranges from 0 to 42 , with higher scores indicating greater severity.

the telmisartan group and $28.2 \%$ in the placebo group; ACE inhibitors, $28.4 \%$ and $33.9 \%$, respectively; calcium-channel blockers, $26.5 \%$ and $30.9 \%$, respectively; and beta-blockers, $22.3 \%$ and $25.4 \%$, respectively.

\section{BLOOD PRESSURE, CREATININE, AND POTASSIUM}

At 1 month, there was a reduction in average systolic blood pressure of $8.3 \mathrm{~mm} \mathrm{Hg}$ in the telmisartan group, as compared with a reduction of 2.9 $\mathrm{mm} \mathrm{Hg}$ in the placebo group (between-group difference, $5.4 \mathrm{~mm} \mathrm{Hg}$ ) (Fig. 1 in the Supplementary Appendix). However, at 1 year, the betweengroup difference in systolic blood pressure favoring telmisartan had narrowed to $4.0 \mathrm{~mm} \mathrm{Hg}$, with an average difference of only $3.8 \mathrm{~mm} \mathrm{Hg}$ between the two groups throughout the study. Although the between-group difference in diastolic blood pressure favoring telmisartan was $2.9 \mathrm{~mm} \mathrm{Hg}$ at 1 month, it narrowed to $2.2 \mathrm{~mm} \mathrm{Hg}$ at 1 year and to $1.6 \mathrm{~mm} \mathrm{Hg}$ by the end of the study, with an average between-group difference favoring telmisartan of $2.0 \mathrm{~mm} \mathrm{Hg}$.

In the two groups, the mean creatinine level at baseline was $1.0 \mathrm{mg}$ per deciliter $(88 \mu \mathrm{mol}$ per liter), and the mean potassium level was $4.1 \mathrm{mmol}$ per liter. At 1 month, the mean creatinine level increased by $0.06 \mathrm{mg}$ per deciliter $(5 \mu \mathrm{mol}$ per liter) in the telmisartan group and $0.09 \mathrm{mg}$ per deciliter ( $8 \mu \mathrm{mol}$ per liter) in the placebo group. At the same time, the mean potassium level increased by $0.22 \mathrm{mmol}$ per liter in the telmisartan group and $0.13 \mathrm{mmol}$ per liter in the placebo group. At 1 month, the proportion of patients with a creatinine level of more than $1.5 \mathrm{mg}$ per deciliter (133 $\mu \mathrm{mol}$ per liter) was similar in the telmisartan group and the placebo group $(6.2 \%$ and $5.8 \%$, respectively), whereas the proportion of patients with a potassium level of more than 5.5 mmol per liter was significantly higher in the telmisartan group than in the placebo group $(1.6 \%$ and $0.8 \%$, respectively; $\mathrm{P}<0.001$ ).

\section{ADVERSE EVENTS}

Adverse events leading to discontinuation of a study medication are listed in Table 2. The listed adverse events were selected on the basis of medical interest and the mechanism of action of tel- 


\begin{tabular}{|c|c|c|c|}
\hline \multirow[t]{2}{*}{ Adverse Event } & $\begin{array}{l}\text { Telmisartan } \\
(\mathrm{N}=10,146)\end{array}$ & $\begin{array}{c}\text { Placebo } \\
(\mathrm{N}=10,186)\end{array}$ & \multirow[t]{2}{*}{ P Value } \\
\hline & \multicolumn{2}{|c|}{ no. (\%) } & \\
\hline Total & $1450(14.3)$ & $1127(11.1)$ & $<0.001$ \\
\hline Hypotensive symptoms & $393(3.9)$ & $186(1.8)$ & $<0.001$ \\
\hline Syncope & $21(0.2)$ & $6(0.1)$ & 0.004 \\
\hline Uncontrolled hypertension & $13(0.1)$ & $17(0.2)$ & 0.47 \\
\hline Headache & $231(2.3)$ & $203(2.0)$ & 0.16 \\
\hline Diarrhea & $69(0.7)$ & $45(0.4)$ & 0.02 \\
\hline Nausea & $104(1.0)$ & $72(0.7)$ & 0.01 \\
\hline Vomiting & $74(0.7)$ & $61(0.6)$ & 0.25 \\
\hline Angioedema & $23(0.2)$ & $31(0.3)$ & 0.28 \\
\hline Renal impairment & $28(0.3)$ & $18(0.2)$ & 0.14 \\
\hline Hyperkalemia & $14(0.1)$ & $6(0.1)$ & 0.07 \\
\hline Atrial fibrillation & $81(0.8)$ & $50(0.5)$ & 0.006 \\
\hline
\end{tabular}

misartan. Hypotension or syncope led to study discontinuation significantly more often in the telmisartan group than in the placebo group.

\section{PRIMARY AND SECONDARY OUTCOMES}

There was no significant interaction between the results of the antiplatelet comparison and the comparison between telmisartan and placebo $(\mathrm{P}=0.35$ for interaction). The primary outcome of first recurrent stroke occurred in 880 patients $(8.7 \%)$ in the telmisartan group, as compared with 934 patients $(9.2 \%)$ in the placebo group (hazard ratio, 0.95; $95 \%$ confidence interval [CI], 0.86 to 1.04 ; $\mathrm{P}=0.23$ ) (Fig. 1 and Table 3). This nonsignificant difference was consistent across various subtypes of stroke. Post hoc exploratory analyses indicated that the number of patients who had a recurrent stroke during the first 6 months was 347 (3.4\%) in the telmisartan group, as compared with 326 $(3.2 \%)$ in the placebo group (hazard ratio, 1.07; $95 \%$ CI, 0.92 to 1.25). After 6 months, 533 patients $(5.3 \%)$ had a recurrent stroke in the telmisartan group, as compared with $608(6.0 \%)$ in the placebo group (hazard ratio, 0.88; $95 \% \mathrm{CI}$, 0.78 to 0.99 ). The difference in effects that were observed during the two periods was significant $(\mathrm{P}=0.04$ for interaction).

The number of patients with a major cardiovascular event was 1367 (13.5\%) in the telmisartan group, as compared with 1463 (14.4\%) in the placebo group (hazard ratio, 0.94; 95\% CI, 0.87 to 1.01) (Fig. 2A and Table 3). Post hoc exploratory analyses indicated that the number of such events occurring within 6 months after randomization was 474 (4.7\%) in the telmisartan group, as compared with $433(4.3 \%)$ in the placebo group (hazard ratio, 1.10 ; $95 \% \mathrm{CI}, 0.97$ to 1.26 ). However, after 6 months, the number of such events was lower in the telmisartan group than in the placebo group, with 893 events (8.8\%) and 1030 events $(10.1 \%)$, respectively (hazard ratio, 0.87 ; $95 \% \mathrm{CI}, 0.80$ to $0.95 ; \mathrm{P}=0.004$ for interaction between the two periods). Adjustment for postrandomization differences in blood pressure did not materially affect the estimated treatment effects of telmisartan for stroke, either overall (hazard ratio, $0.96 ; 95 \% \mathrm{CI}, 0.87$ to 1.05 ) or at more than 6 months (hazard ratio, $0.89 ; 95 \% \mathrm{CI}$, 0.79 to 1.00 ), or for major cardiovascular events, either overall (hazard ratio, $0.94 ; 95 \% \mathrm{CI}, 0.87$ to 1.01) or at more than 6 months (hazard ratio, 0.88 ; $95 \%$ CI, 0.81 to 0.96 ).

The number of patients who had new-onset diabetes after randomization was $125(1.2 \%)$ in the telmisartan group, as compared with 151 (1.5\%) in the placebo group (hazard ratio, 0.82; $95 \% \mathrm{CI}$, 0.65 to $1.04 ; \mathrm{P}=0.10$ ) (Fig. $2 \mathrm{~B}$ and Table 3 ).

\section{OTHER OUTCOMES}

There were no significant differences between the telmisartan group and the placebo group in the number of patients who died (755 vs. 740), had a major hemorrhage (385 vs. 399), had migraine in the first 6 months (429 vs. 447), or had headache in the first 7 days (2006 vs. 2102). The number of patients who had intracranial bleeding did not differ significantly between the telmisartan group (112 patients) and the placebo group (138 patients) $(1.1 \%$ vs. $1.4 \%$; hazard ratio, $0.81 ; 95 \%$ CI, 0.63 to 1.05$)$.

\section{SUBGROUP ANALYSES}

In prespecified subgroups of patients, results for stroke (Fig. 3A) and for major cardiovascular events (Fig. 3B) indicated no heterogeneity of effects. Separate analyses of patients who underwent early randomization ( $<10$ days after a stroke) showed results similar to those in the entire study cohort. At 30 days in this subgroup, there was no significant increase in risk in the telmisartan group, as compared with the placebo group, for stroke (51 patients vs. 44 patients) or for major cardiovascular events ( 72 patients vs. 56 patients). 


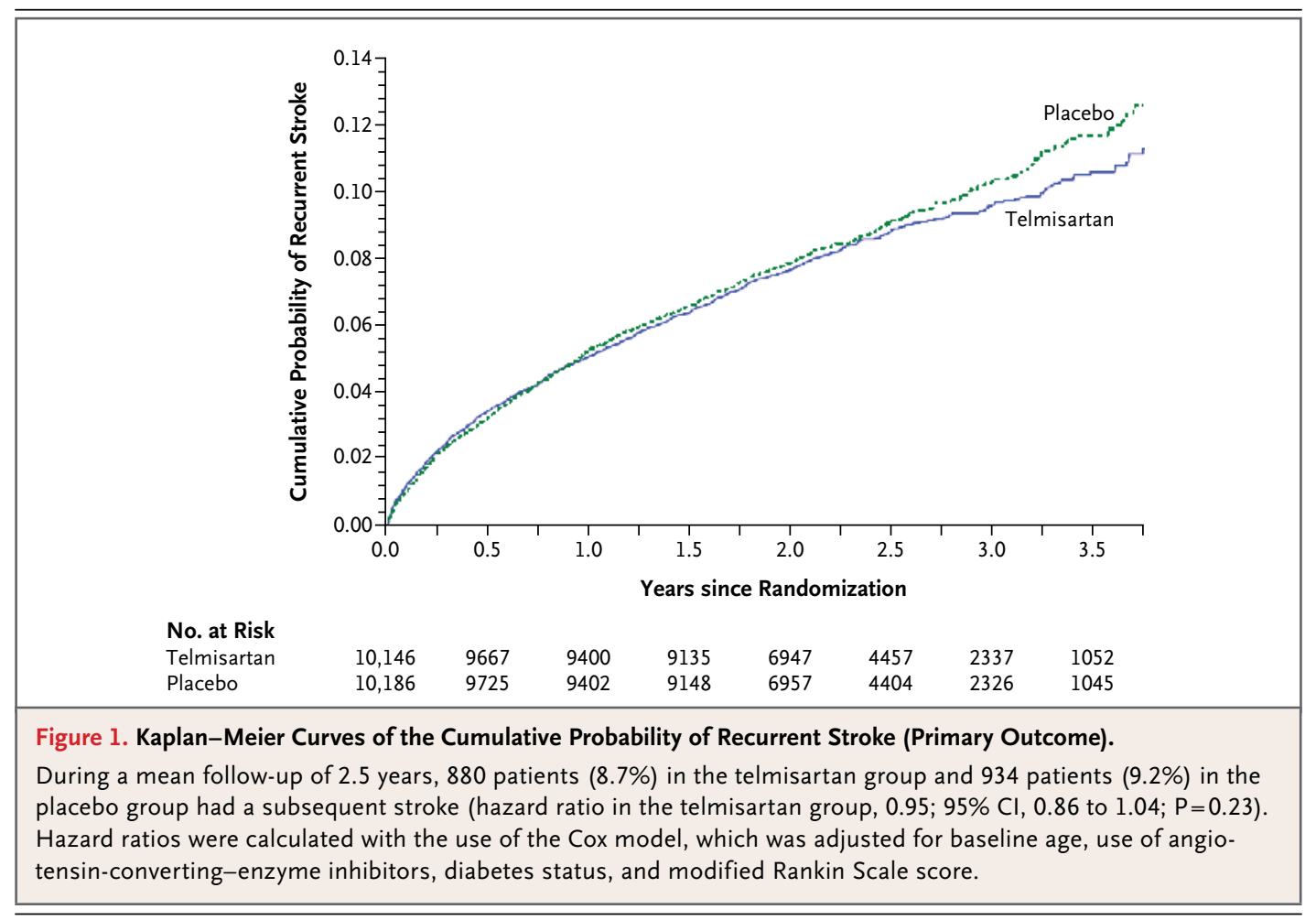

\section{DISCUSSION}

In our study, we compared telmisartan with placebo initiated soon after an ischemic stroke, with patient follow-up for an average of 2.5 years. We showed that telmisartan did not significantly reduce the risk of a subsequent stroke, of the composite outcome of major cardiovascular events, or of new-onset diabetes.

Elevated blood pressure after a stroke is associated with recurrent events, and long-term lowering of blood pressure reduced recurrent strokes in the PROGRESS study. ${ }^{3}$ At first glance, the data from our trial may appear to be discrepant with those from the PROGRESS trial. However, there are several differences between the studies. First, at baseline, patients' mean blood pressure was higher in the PROGRESS study (147/86 $\mathrm{mm} \mathrm{Hg})$ than in our study $(144 / 84 \mathrm{~mm} \mathrm{Hg})$. Second, a majority of patients (58\%) in the PROGRESS study were assigned to receive a combination of perindopril plus indapamide, which reduced blood pressure to a substantial degree $(12.3 / 5.0 \mathrm{~mm} \mathrm{Hg})$, as compared with those receiving an ACE inhibitor only, for whom the blood pressure reduction was more modest (4.9/2.8 $\mathrm{mm} \mathrm{Hg})$. The reduction of stroke in the PROGRESS study was seen large- ly among patients receiving combination therapy. The smaller reduction in blood pressure in our study and the lower initial blood pressure levels may in part explain the apparent differences in the results.

The results of our analysis were unaltered after accounting for the modest reduction in blood pressure in the telmisartan group. This finding raises the question of whether agents that block the renin-angiotensin system offer additional benefit independent of their effects on blood pressure. In both the HOPE study ${ }^{5,6}$ and the Losartan Intervention for End-point Reduction in Hypertension (LIFE) study (ClinicalTrials.gov number, NCT00338260), ${ }^{10}$ it was suggested that such mechanisms may be important. However, in the PROGRESS trial, a clear reduction in the risk of stroke was observed only in the group that received a combination of perindopril plus a diuretic, which reduced systolic blood pressure by $12 \mathrm{~mm} \mathrm{Hg}$. No significant reduction in the risk of stroke occurred in patients receiving perindopril alone, which reduced systolic blood pressure by a more modest $5 \mathrm{~mm} \mathrm{Hg}{ }^{3}$ The role of ARBs is currently being further evaluated in two large trials with expected mean follow-ups of more than 4 years. ${ }^{11,12}$ 


\begin{tabular}{|c|c|c|c|c|}
\hline \multirow[t]{2}{*}{ Outcome } & $\begin{array}{l}\text { Telmisartan } \\
(\mathrm{N}=10,146)\end{array}$ & $\begin{array}{c}\text { Placebo } \\
(\mathrm{N}=10,186)\end{array}$ & $\begin{array}{l}\text { Hazard Ratio } \\
(95 \% \mathrm{Cl})^{*}\end{array}$ & $P$ Value \\
\hline & \multicolumn{2}{|c|}{ no. (\%) } & & \\
\hline \multicolumn{5}{|l|}{ Primary } \\
\hline Recurrent stroke $\dagger$ & $880(8.7)$ & $934(9.2)$ & $0.95(0.86-1.04)$ & 0.23 \\
\hline Ischemic & $774(7.6)$ & $811(8.0)$ & & \\
\hline Hemorrhagic & $59(0.6)$ & $69(0.7)$ & & \\
\hline Other or unknown & $47(0.5)$ & $54(0.5)$ & & \\
\hline \multicolumn{5}{|l|}{ Secondary } \\
\hline $\begin{array}{l}\text { Death from cardiovascular causes, recurrent stroke, myocardial } \\
\text { infarction, or new or worsening heart failure }\end{array}$ & $1367(13.5)$ & $1463(14.4)$ & $0.94(0.87-1.01)$ & 0.11 \\
\hline Death from cardiovascular causes & $223(2.2)$ & $263(2.6)$ & & \\
\hline Recurrent stroketr & $855(8.4)$ & $914(9.0)$ & & \\
\hline Myocardial infarction & $168(1.7)$ & $169(1.7)$ & & \\
\hline New or worsening heart failure & $121(1.2)$ & $117(1.1)$ & & \\
\hline New-onset diabetes & $125(1.2)$ & $151(1.5)$ & $0.82(0.65-1.04)$ & 0.10 \\
\hline \multicolumn{5}{|l|}{ Tertiary } \\
\hline $\begin{array}{l}\text { Death from cardiovascular causes, recurrent stroke, or myocar- } \\
\text { dial infarction } \int\end{array}$ & $1289(12.7)$ & $1377(13.5)$ & $0.94(0.87-1.02)$ & 0.13 \\
\hline Death from any cause & $755(7.4)$ & $740(7.3)$ & $1.03(0.93-1.14)$ & 0.55 \\
\hline Death from cardiovascular causes or recurrent stroke & $1171(11.5)$ & $1249(12.3)$ & $0.94(0.87-1.02)$ & 0.15 \\
\hline
\end{tabular}

* Hazard ratios are for patients in the telmisartan group, as compared with the placebo group.

$\uparrow$ Numbers are based on the incidence of the first recurrent stroke.

This event was the first that occurred in the composite outcome.

$\int$ This composite was included for direct comparison with results from the Heart Outcomes Prevention Evaluation (HOPE) trial.

q This outcome was a post hoc composite.

Post hoc exploratory analyses suggested that there was no significant difference in event rates in the first 6 months after randomization for the primary outcome and for two of the secondary outcomes, with a difference emerging later. These findings, while provisional, suggest that the effect of telmisartan in our study was time dependent. In the HOPE and PROGRESS trials, there was little or no apparent benefit in the first 6 months, whereas there was a gradual and continuing lowering in the rates of stroke and major cardiovascular events thereafter. If this interpretation is correct, then the mean duration of follow-up in our study (2.5 years), which was shorter than that of the HOPE study (4.5 years) and the PROGRESS study (4 years), may have contributed to the lack of significant benefit associated with telmisar$\tan$ in our study.

We cannot rule out the possibility that telmisartan therapy is associated with a modest increase in risk during the first 6 months of treatment.
Patients in our study were treated, on average, earlier after their index stroke than in other trials (a median of 15 days, as compared with a median of 8 months in the PROGRESS study). Mildly elevated blood pressure in the acute post-stroke period may be associated with a more favorable outcome, perhaps because it preserves perfusion to ischemic regions. ${ }^{13,14}$ However, in the Acute Candesartan Cilexetil Therapy in Stroke Survivors (ACCESS) study, ${ }^{8}$ in which treatment with an ARB was initiated within the first few days after a stroke, an early benefit was reported. Further subdivision of our data to focus only on patients who were treated very soon after a stroke ( $\leq 10$ days) did not suggest a concentration of harm during the first 30 days of the study.

In our analysis, there was a nonsignificant trend toward a lower rate of new-onset diabetes associated with telmisartan. Several previous trials have suggested that ACE inhibitors and ARBs can reduce the risk of diabetes, ${ }^{15,16}$ although no 


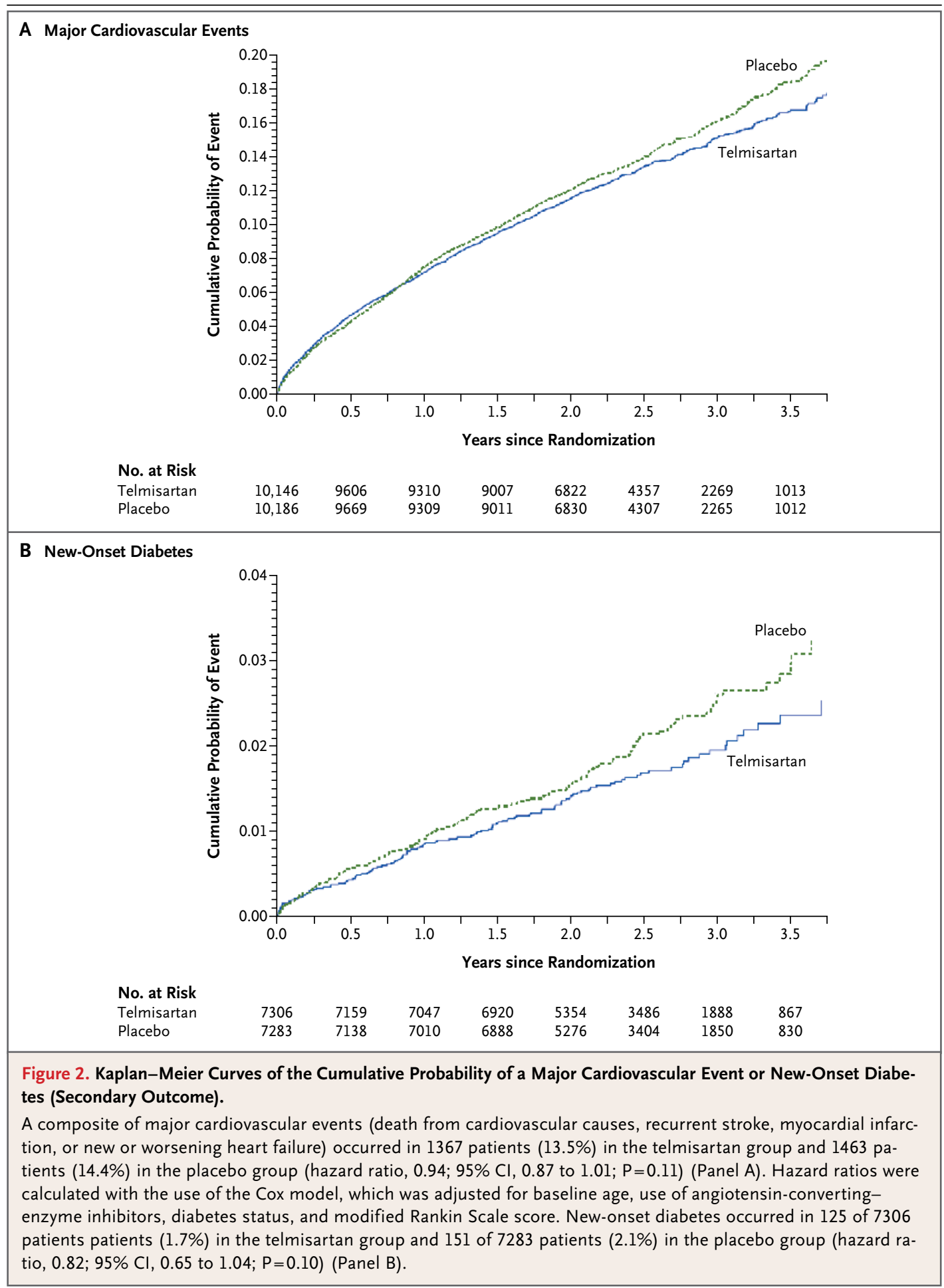

significant benefit was shown in the only large randomized trial in which diabetes was the primary outcome. ${ }^{17}$

Our trial had a few limitations. First, the adherence to the telmisartan regimen was lower than that in other large trials of telmisartan, such as the Ongoing Telmisartan Alone and in Combination with Ramipril Global End-point Tri- 


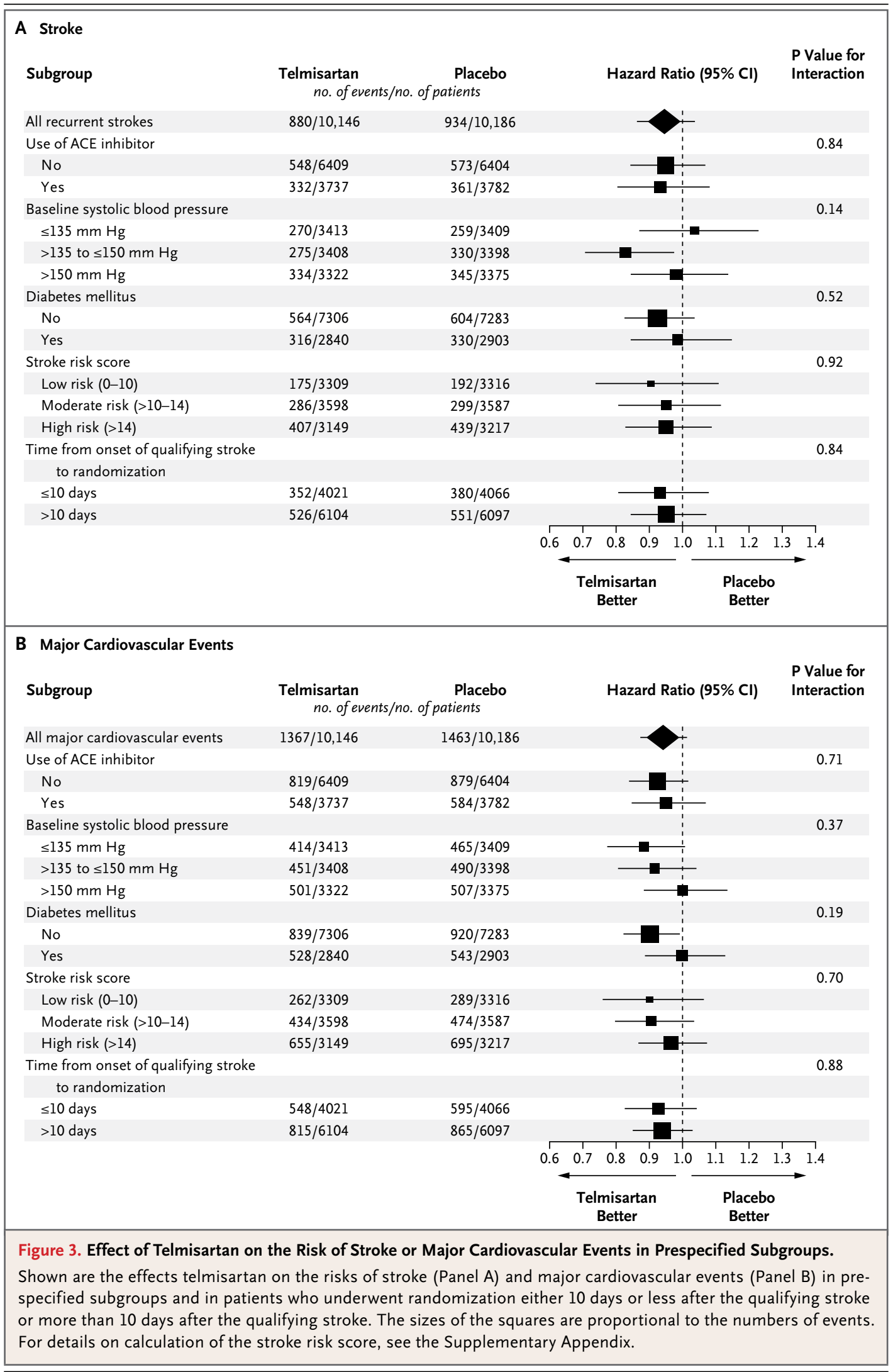


al (ONTARGET; NCT00153101). ${ }^{18}$ This may have been due in part to the absence of a run-in period in our study and to the fact that most patients who had headache caused by aspirin plus extended-release dipyridamole stopped both sets of blinded medications in the factorial design. Second, in our study, more patients in the placebo group than in the telmisartan group received nonstudy blood-pressure-lowering medications (including ACE inhibitors), consistent with the protocol, which strongly emphasized blood-pressure control for all enrolled patients. These factors substantially minimized the difference in blood pressure between the telmisartan group and the placebo group by about one third and may also have contributed to a lack of a significant reduction in events. Third (as discussed above), the duration of the trial may have been too short.

In conclusion, we showed that the addition of ARB therapy to the use of other antihypertensive drugs soon after a stroke and continuing for a mean of 2.5 years did not significantly reduce the risk of subsequent stroke, major cardiovascular events, or new-onset diabetes.

Supported by Boehringer Ingelheim. In selected countries, the telmisartan comparison was supported by Bayer Schering Pharma and GlaxoSmithKline.

Dr. Yusuf reports receiving consulting and lecture fees from Boehringer Ingelheim, Sanofi-Aventis, Bristol-Myers Squibb, AstraZeneca, and GlaxoSmithKline and grant support from Sanofi-Aventis, Bristol-Myers Squibb, and GlaxoSmithKline; Dr. Diener, receiving honoraria, consulting, and lecture fees from Abbott, AstraZeneca, Bayer Vital, Bristol-Myers Squibb, Boeh- ringer Ingelheim, D-Pharm, Fresenius, GlaxoSmithKline, Janssen Cilag, Merck, Novartis, Novo Nordisk, Paion, Parke-Davis, Pfizer, Sanofi-Aventis, Sankyo, Servier, Solvay, Thrombogenics, Wyeth, and Yamaguchi and grant support from AstraZeneca, GlaxoSmithKline, Boehringer Ingelheim, Novartis, JanssenCilag, and Sanofi-Aventis; Dr. Sacco, receiving consulting fees from Boehringer Ingelheim, GlaxoSmithKline, and SanofiAventis and lecture fees from Boehringer Ingelheim; Mr. Cotton, Mr. Lawton, and Drs. Ôunpuu, Gu, Hermansson, Hilbrich, Machnig, VanderMaelen, and Voigt, being employees of Boehringer Ingelheim; Drs. Palesch and Martin, receiving consulting fees from Boehringer Ingelheim; Dr. Albers, receiving consulting and lecture fees from Boehringer Ingelheim and grant support from Boehringer Ingelheim, NMT Medical, Parexel International, AstraZeneca, and Forest Research Institute; Drs. Bath, Chen, De Keyser, and Estol, receiving consulting fees from Boehringer Ingelheim; Dr. Dahlöf, receiving consulting fees from Boehringer Ingelheim, Daiichi Sankyo, and Novartis and lecture fees from Boehringer Ingelheim, Novartis, and Pfizer; Drs. Donnan and Kaste and Mr. Roberts, receiving consulting and lecture fees from Boehringer Ingelheim; Dr. Gorelick, receiving consulting fees from Boehringer Ingelheim, Bayer, TAP Pharmaceutical Products, Myriad, Pfizer, Takeda, Daiichi Sankyo, Novartis, Merck, Brainsgate, and D-Pharm and lecture fees from Boehringer Ingelheim and diaDexus; Dr. Pais, receiving consulting fees and grant support from Boehringer Ingelheim; Dr. Teal, receiving consulting and lecture fees from SanofiAventis, Bristol-Myers Squibb, and Boehringer Ingelheim and consulting fees from Bayer; Dr. Toni, receiving consulting fees from Boehringer Ingelheim and lecture fees from Boehringer Ingelheim, Sanofi-Aventis, and Novo Nordisk; and Dr. Weber, receiving consulting and lecture fees or honoraria from Novartis, Bristol-Myers Squibb, Daiichi Sankyo, Boehringer Ingelheim, GlaxoSmithKline, and Forest Laboratories, consulting fees from Gilead and Takeda, and lecture fees or honoraria from SanofiAventis. No other potential conflict of interest relevant to this article was reported.

We thank Colette Easton, Judy Lindeman, and Vicky Hinstridge for their technical assistance and Karuna Bellamkonda and Michael Pannucci for their programming support.

APPENDIX

The authors' affiliations are as follows: the Population Health Research Institute (S.Y.) and the Clinical Trials Methodology Group (R.R.), McMaster University; and Hamilton Health Sciences (S.Y.) - all in Hamilton, ON, Canada; the University of Duisberg-Essen, Essen, Germany (H.-C.D.); the Miller School of Medicine, University of Miami, Miami (R.L.S.); Boehringer Ingelheim, Ridgefield, CT (D.C., L.H., C.V., T.V.), Burlington, ON, Canada (S.O.), Bracknell, United Kingdom (W.A.L.), Shanghai, China (V.G.), Stockholm (K.H.), and Ingelheim, Germany (T.M.); the Medical University of South Carolina, Charleston (Y.P., R.H.M.); Stanford University Medical Center, Palo Alto, CA (G.W.A.); the University of Nottingham, Nottingham, United Kingdom (P.B.); Ichilov Medical Center, Tel-Aviv, Israel (N.B.); National University Hospital, Singapore (B.P.L.C.); Chang Gung Memorial Hospital, Tapei, Taiwan (S.-T.C.); Hospitais da Universidade de Coimbra, Coimbra, Portugal (L.C.); Sahlgrenska University Hospital/Östra, Göteborg, Sweden (B.D.); University Medical Center Groningen, Groningen, the Netherlands (J.D.K.); National Stroke Research Institute, Austin Health, University of Melbourne, Heidelberg West, Australia (G.A.D.); Neurological Center for Treatment and Research, Buenos Aires (C.E.); University of Illinois, Chicago (P.G.); Helsinki University Central Hospital, Helsinki (M.K.); Huashan Hospital, Shanghai, China (C.L.); St. Johns's Medical College, Bangalore, India (P.P.); Russian State Medical University, Moscow (V.S.); University of British Columbia, Vancouver, Canada (P.T.); University La Sapienza, Rome (D.T.); SUNY DownState College of Medicine, New York (M.W.); and Seoul National University Hospital, Seoul, South Korea (B.-W.Y.).

Investigators in the PRoFESS study are as follows: Trial Management and Steering Committee: Current members of the trial management committee are denoted by an asterisk. Previous members are denoted by a dagger. H.-C. Diener (cochair), ${ }^{\star}$ R. Sacco (cochair), ${ }^{\star}$ S. Yusuf (cochair), ${ }^{\star}$ B. Blank, $\uparrow$ D. Cotton, ${ }^{\star}$ V. Gu, ${ }^{\star}$ K. Hermansson, ${ }^{\star}$ L. Hilbrich, $\uparrow$ M. Humphreys, $\uparrow$ W.A. Lawton, ${ }^{\star}$ T. Machnig, S. Ônpuu, ${ }^{\star}$ C. VanderMaelen, ${ }^{\star}$ T. Voigt, ${ }^{\star}$ Y. Wu, $\nmid$ G. Albers, P. Bath, N. Bornstein, B. Chan, S.-T. Chen, L. Cunha, B. Dahlöf, J. DeKeyser, G. Donnan, C. Estol, P. Gorelick, M. Kaste, C. Lu, P. Pais, R. Roberts, V. Skvortsova, P. Teal, D. Toni, M. Weber, B.-W. Yoon. Data and Safety Monitoring Committee: P. Wolf (chair), M. Fisher, B. Norrving, Y. Palesch (independent statistician), P. Sleight, A. Turpie. Adjudication Committee: T. Buck, J. Chong, G. Dagenais, R. delaPaz, A. Diehl, M. DiTullio, D. Easton, C. Ehrenfeld, M. Elkind, J. Fiebach, M. Forsting, E. Gizewski, D. Gohs, J. Halperin, M. Haude, C. Herz, S. Homma, O. Kastrup, J. Krakauer, A. Magun, M. Maschke, J.P. Mohr, C. Möller-Hartmann, P. Mummel, J. Pile-Spellman, C. Rodriguez, S. Sack, J. Schlaak, A. Schmermund, R. von Kummer, I. Wanke, C. Weimar, H. Wieneke, T. Zoepf. Publication Committee: H.-C. Diener (chair), P. Bath, G. Donnan, D. Cotton, C. Estol, L. Hilbrich, † M. Humphreys, '† S. Ônpuu, R. Roberts, P. Teal, D. Toni, R. Sacco, S. Yusuf. Substudy Subcommittee: P. Bath (cochair), R. Sacco (cochair), D. Cotton, B. Dahlöf, H.-C. Diener, P. Gorelick, R. Roberts, M. Weber, S. Yusuf, L. Hilbrich.† Principal Investigators by Country: Argentina: C. Estol (national coordinator), S. Ameriso, D. Baumann, J.J. Cirio, T.S. Coleman, M.M. Esnaola y-Rojas, H. Fraiman, H. Gabrielli, J. 
Garrote, M. Garrote, P. loli, J.L. Ferreiro, S. Lepera, M.F. Pardal, R. Rey, A. Ruiz, G. Saredo, C. Simonsini, A. Zinnerman. Australia: G. Donnan (national coordinator), C. Bladin, D. Crimmins, S. Davis, J. Frayne, P. Hand, R. Henderson, N. Ingham, C. Levi, M. Parsons, S. Read, D. Schultz, A. Slattery, M. Williams, J.A. Zavala. Austria: S. Horner (national coordinator), F. Aichner, M. Brainin, U. Baumhackl, T. Brücke, W. Doppler, V. Dorda, H.-P. Haring, A. Seiser, H.W. Wege, G. Wille, J. Willeit. Belgium: S. Blecic (national coordinator), $\uparrow$ V. Thijs (national coordinator), B. Bruneel, J. Caekebeke, N. De Klippel, A. De Windt, P.P. De Deyn, P. Desfontaines, S. Dethy, M. Dupuis, A. Görner, S. Jeangette, P. Laloux, M. Pandolfo, A. Peeters, R. Sheorajpanday, W. Van Landegem, P. Vermylen, G. Vanhooren, C. Willems. Brazil: A.R. Massaro (national coordinator), C. André, A.C.F. Almeida, R. Brondani, J.J. Carvalho, F. Cendes, G.R. de Freitas, S.R.F. Fábio, M.A.G. Friedrich, M. Martins, S.C.O. Martins, A.B. Maulaz, C. Minelli, C.H.C. Moro, J. Oliveira-Filho, M.S. Rocha, J.I. Siqueira-Neto, R. Valiente, V.H.F. Zétola. Canada: P. Teal (national coordinator), N. Amir, B.A. Anderson, R. Arts, P. Bailey, N. Bayer, M. Beaudry, L. Berger, J.-M. Boulanger, D. Brunet, T. Collier, R. Côté, V. Daniels, A. Demchuk, H. Desai, A.M. Fontaine, M. Gawel, D. Gladstone, W. Goldstein, V. Hachinski, F. Herbert, K. Hesser, H. Hink, K. Ho, D. Howse, K. Kastelic, P. Kostyrko, M. Lapierre, L.-H. Lebrun, A. Mackey, M. Maharaj, L. Miners, J. Minuk, G. Moddel, R. Mosewich, D. Novak, A. Penn, Y. Pesant, P. Pikl, A. Rabinovitch, H. Rabinovitch, D. Sahlas, C. Schanz, J. Scott, D. Selchen, M. Sharma, A. Shuaib, J. Silva, F.L. Silver, D. Spence, M. Stefanelli, S. Stoger, T. Stokes, J. Teitelbaum, F. Veloso, S. Verreault, C. Voll, C. Walker, S. Walker, R. Wiegner, T. Winder, M. Winger, A. Woolfenden. China: C. Lu (national coordinator), D.W. Chen, H.B. Chen, S.D. Chen, Y. Cheng, Z.F. Chi, L.Y. Cui, Q. Di, F. Deng, M.P. Ding, S.J. Ding, X.S. Ding, D.S. Fan, W. Fan, X.B. Fan, H.L. Feng, J. Gong, T. Gong, Z. Hong, X.J. Hou, X.Q. Hu, Y.N. Huang, C.Y. Li, L. Li, T. Li, W. Li, Z.Y. Li, H. Lin, Q.Y. Lin, C.F. Liu, J.R. Liu, J.R. Liu, M. Liu, R. Liu, X.F. Liu, Y. Liu, G.G. Luo, G.Q. Luo, J.T. Miao, L. Miao, Z.Y. Pang, W. Qiu, B. Shao, X.J. Sun, D.X. Wang, F. Wang, L.J. Wang, S.Z. Wang, W. Wang, Y.J. Wang, J. Wu, J. Xia, E. Xu, H.Q. Xu, S.B. Xu, X. Xu, Q.D. Yang, X. Yi, P.M. Yu, G.L. Zeng, J.S. Zeng, Y. Zhai, B. Zhang, C.Y. Zhang, H. Zhang, S.H. Zhang, W.W. Zhang, Y.B. Zhang, Y. Zhang, Y. Zhang, G. Zhao, J.H. Zhao, J. Zhao, G.X. Zhou, H.D. Zhou, X.Q. Zhao, G.M. Zhu, Y.C. Zhu. Denmark: P. Petersen (national coordinator), G. Andersen, P. Arlien-Soeborg, I.C. Bach, M. Binzer, G. Boysen, A. Heick, A.-M. Homburg, S. Husted, H. Iversen, L.-H. Krarup, T.S. Olsen, K. Overgaard, P. Von Weitzel-Mudersbach. Finland: M. Kaste (national coordinator), M. Hillbom, K. Koivisto, M. Männikkö, S. Mustanoja, H. Numminen, J. Nuutinen, J. Sivenius. France: X. Ducrocq (national coordinator), D. Leys, C. Lucas, F. Macian, L. Milandre, J.-P. Neau, D. Saudeau, H. Vespignani, M. Voicu, M. Zuber. Germany: O. Busse (national coordinator), A. Ahlers, J. Allendoerfer, R. Benecke, S. Boy, A. Dethlefs, M. Dichgans, H.-C. Diener, M. Eicke, F. Erbguth, G. Gahn, S. Gass, J. Glahn, M. Görtler, A. Grau, B. Griewing, M. Grond, K.-H. Grotemeyer, J. Haan, G. Hamann, L. Harms, S. Harscher, A. Hetzel, A. Hoferichter, H.B. Huelsboemer, G. Ickenstein, M. Kaps, M. Kirchner, H. Kunte, J. Liepert, R. Malessa, Y. Mewald, A. Müller-Jensen, D. Nabavi, M. Nedelmann, M. Nueckel, H. Poppert, K. Rabe, J. Regula, P. Ringleb, M. Rosenkranz, W.-R. Schaebitz, I. Schaberger, F. Schlachetzki, D. Schneider, J. Schrader, U. Sliwka, J. Sobesky, H. Soda, W. Steinke, H.G. Thomalla, H. Topka, J. Treib, M. Vry, T. Warnecke, R. Weber, C. Weiller, K. Wessel, H. Wiethölter, O. Witte, H. Wuttig. Greece: I. Iliopoulos (national coordinator), I. Ellul, S. Giannopoulos, C. Karageorgiou, P. Papathanasopoulos, D. Vassilopoulos, S. Voyaki. Hong Kong: P.W. Ng (national coordinator), B.H. Fung, K.F. Hui, T. Leung, V. Mok, K.S. Wong. India: D. Xavier (national coordinator), A. Agarwal, R.R. Agrawal, A.M. Anandan, V. Anandhi, G.K. Babu, S. Bandishti, A. Bhargava, N. Bhargava, A. Bharani, A. Bhatt, N. Chidambaram, Y. Dewan, M. Dinaker, R. Joshi, S. Joshi, A. Kalanidhi, S.P. Kalantri, S. Kothari, A. Kumar, P. Kumar, V. Jain, M.M. Mehndiratta, S. Mijar, V. Mishra, S. Murali, R.S. Muralidharan, J.M.K. Murthy, R. Nair, J.T. Narayanan, R.B. Panwar, P. Patel, F. Poncha, V.V.R. Prasad, A. Rath, B.C.S. Reddy, A. Rohatgi, A.K. Roy, S. Sadanandham, A. Salam, G.R.K. Sarma, H. Singh, Y. Singh, S. Shanmugasundaram, S. Sharma, S. Sivakumar, R. Sundararajan, T. Sundararajan, U. Tukaram, R. Umarani, S. Varma, C.U. Velmurugendran, A. Venkitachalam, R. Verghese, K.P. Vinayan, A. Vyas, R.S. Wadia. Ireland: R. Galvin (national coordinator), P. Kelly, D. O'Mahony. Israel: N. Bornstein (national coordinator), B. Assa-Meirov, B. Gross, Y. Lampl, A. Mahagney, O. Merzlyak, R. Milo, M. Rabey, L. Shopin, J. Streifler, D. Tanne, G. Telman, L. Turiansky, B. Weller, D. Yarnitsky. Italy: L. Provinciali (national coordinator), M. Arnaboldi, P. Bassi, B. Bergamasco, A. Carolei, G. Cascone, F. Chiodo Grandi, G. Comi, D. Consoli, F. Corea, P. Dudine, F.A. De Falco, C. Gandolfo, E. Giaccaglini, B. Gobbi, D. Inzitari, G. Lembo, M. Melis, R. Mutani, E. Natalé, G. Neri, M. Rasura, M.L. Sacchetti, A. Semplicini, M. Stornello, M. Stramba-Badiale, R. Sterzi, G. Torcasio, V. Toso. Japan: S. Uchiyama (national coordinator), T. Yamaguchi (national coordinator), K. Chiba, Y. Fujino, F. Hattori, K. Hattori, O. Hirai, A. Imamura, K. Ishii, T. Ishihara, M. Isobe, K. Ito, T. Jinnouchi, M. Kaido, T. Kawamoto, M. Kawanishi, I. Kim, K. Kitazawa, M. Kotera, Y. Kujiraoka, S. Kurokawa, Y. Maeda, K. Matsumoto, M. Matsumoto, S. Matsumoto, F. Nakagawa, Y. Nakajima, T. Obata, H. Ohnishi, N. Sato, T. Seguchi, T. Seki, Y. Shibagaki, M. Shitamichi, A. Tabuchi, K. Takahashi, M. Takekawa, Y. Takimoto, H. Tanabe, H. Taniguchi, Y. Tatsuoka, K. Toda, T. Toriyama, M. Yamazaki, H. Yoshida. Malaysia: K.S. Tan (national coordinator), T. Hassan, H.T. Chong, K.S. Tan, J.K.J. Tharakan. Mexico: A. Arauz (national coordinator), J. Aguayo, C. Cantu, C. Espinoza, J. Fernández-Vera, J. Guzman, C. León, A. Leyva, M. López, M. López-Ruiz, S. Reyes, J. Ruiz, R. Vazquez, J. Villarreal. the Netherlands: J. De Keyser (national coordinator), M. Aramideh, J. Boiten, P. Brouwers, B. de Bruijn, C. Franke, J. den Heijer, P. Dellemijn, J. Hagemans, K. Keizer, S. Kok, P. de Kort, J. de Kruijk, J. Kuipers-Lo Dico, J. van Leusden, H. van Leusen, B. Jansen, W.M. Mulleners, K. ten Napel, J.F. de Rijk-van Andel, J. Van Remmen, W. Rutgers, W.J. Schonewille, T. Simons, T.J. Tacke, E. Vries, J. Wessel, M. van Zagten. Norway: B. Indredavik (national coordinator), H. Næss, G. Rohweder, Ф. Rфsjф. Portugal: L. Cunha (national coordinator), J. Campillo, J.M. Ferro, G. Lopes, A.A. Pinto, V. Salgado. Russia: V. Skvortsova (national coordinator), V. Alifirova, A. Amintaeva, O. Antukhova, G. Avakyan, A. Belkin, A. Belova, A. Boiko, A. Boiko, V. Bulgakov, M. Cherman, N. Dokuchaeva, B. Doronin, M. Evzelman, A. Fedin, N. Fedorova, O. Gileva, M. Glezer, K. Golikov, N. Halo, E. Isakova, A. Ivleva, L. Kabanova, S. Kotov, A. Kovalenko, G. Kozin, T. Lokshtanova, M. Lutsky, R. Magzhanov, M. Martynov, T. Mirsaev, D. Mulyarov, V. Narodova, M. Odinak, A. Orlov, V. Parfenov, N. Pizova, J. Popova, E. Poroshina, S. Pronina, N. Pryanikova, E. Pynchuk, L. Renzhina, A. Savchenko, E. Shirokov, V. Shmyrev, I. Sholomov, N. Shmidt, V. Simanenkov, A. Skoromets V. Sorokoumov, N. Spirin, L. Stakhovskaya, A. Stepanchenko, E. Strachunskaya, V. Stulin, Z. Suslina, S. Timerbaeva, Y. Trinitatsky, Y. Varakin, O. Voskresenskaya, E. Yacupov, N. Yahno, S. Yanishevsky, G. Yudina, Y. Yudelson, J. Zhitkova. Singapore: B.P.L. Chan (national coordinator), H.M. Chang, C.C. Chen, W. Cheong, D.A. De Silva, R.N. Gan, C. Meng, A.B.H. Seah, V.K. Sharma, C.S.P. Soon, N. Venketasubramanian, Y. Wai, M.C. Wong, C.W. Yip. South Africa: J. Smuts (national coordinator), P. Francis, J. Gardiner, W. Guldenpfennig, D. Lurie, A. Mochan, C. Retief, W. Van Niekerk. South Korea: B.-W. Yoon (national coordinator), O.-Y. Bang, K.-H. Cho, S.-W. Han, J.-H. Heo, D.-W. Kang, H.-A. Kim, H.-M. Kwon, J.-H. Kwon, S.-U. Kwon, B.-C. Lee, H.-S. Nam, M.-S. Park, J.-H. Rha, K.-H. Yu. Spain: A. Gil-Nunez (national coordinator), J. Alvarez-Sabín, C. Antón, J.A. Egido, J. Gállego, F. Gracia, J.M. Moltó, R. Navarro, F. Rubio. Sweden: N.-G. Wahlgren (national coordinator), B. Andersson, M. von Arbin, A. Berglund, E. Bertholds, L. Bokemark, C. Carlstroem, A.-C. Elgåsen, J.P. Eriksson, P.-O. Hansson, T.-B. Käll, A. Lindgren, J. Lökk, J. Malm, I. Markström, M. Milovanovic, S.-Å. Nilsson, B. Persson, Ö. Skogar, M. Stenstam, J. Teichert, S. Karlsson-Tivenius, M. Von Euler, T. Wallén. Taiwan: S.-T. Chen (national coordinator), K.-C. Chang, M.-H. Chang, Y.-J. Chang, C.-H. Chen, W.-H. Chen, Y.-T. Chuang, C.-Y. Hsu, H.-H. Hu, Y.-C. Huang W.-J. Hwang, J.-S. Jeng, J.-T. Lee, L.-M. Lien, R.-T. Lin, Y.-J. Lin, C.-H. Liu, G.-S. Peng, H.L. Po, T.-Y. Tan, S.-C. Tsai, S.-F. Wang, W.-J. Wong. Thailand: 
S. Chankrachang, Y. Chinvarun, A. Chutinet, S. Muengtaweepongsa, Y. Nilanont, N. Poungvarin, P. Sithinamsuwan, N. Suwanwela, S. Tanprawate. Turkey: S. Bahar (national coordinator), S. Aktan, M. Bakar, S. Balkan, T. Dalkara, K. Kutluk, G. Ozdemir. Ukraine: S. Moskovko (national coordinator), O. Balyskyy, V. Bitensky, O. Dubenko, L. Dzyak, A. Goloborodko, G. Grebenyuk, A. Koselkin, V. Kulgeyko, S. Kuznetzova, V. Lebedynets, V. Maly, S. Medvedkova, E. Melnyk, T. Mishchenko, G. Moskovko, V. Orzheshkovskyy, N. Ovsyannikova, V. Yavorska, I. Yurdanova, V. Zushkha. United Kingdom: P. Bath (national coordinator), L. Brawn, M. Brown, L. Campbell, D. Cohen, R. Curless, J. Davis, G. Durward, G. Ford, C. Gray, F.L. Hammonds, T. Hendra, M. James, L. Kalra, R. Kumar, S. Jackson, D. Jenkinson, K. Lees, G. Lip, R. MacWalter, K. Muir, P. Murphy, J. Okwera, E. Orugun, P. Passmore, J. Potter, A. Sharma, J. Sharma, M. Sterling, S. Ragab, T. Robinson, C. Roffe, A. Rowe, J. Turton. United States: G. Albers (national coordinator), P. Gorelick (national coordinator), R. Sacco (national coordinator), F. Abbott, J. Absher, A. Acharya, H. Adams, P. Akins, E. Albakri, M. Alberts, R. Alonso, I. Altafullah, E. Anderson, J. Andrefsky, R. Armstrong, G. Arnold, A. Arora, R. Atkinson, S. Azhar, S. Bansil, K. Becker, R. Bell, L. Benardo, G. Bernardini, A. Bernstein, P. Blachman, J. Boiser, B. Boop, C. Boutwell, D. Bressler, C. Brooks, W. Brooks, R. Calhoun, F. Campanella, S. Carlson, D. Carpenter, J. Castaldo, R. Castaldo, M. Cauli, K. Chan, S. Chaturvedi, S. Cherian, M. Chesser, D. Chiu, W. Clark, B. Cleeremans, S. Cohen, T. Coin, L. Collins, M. Concha, G. Cooper, J. Couch, B. Coull, E. Crisostomo, A. Cruz, P. Cullis, R. Dafer, S. Dash, D. Davis, P. Davis, J. DeMatteis, B. Diamond, A. Dick, D. Dietrich, R. Dunnigan, D. Duong, L. Edelsohn, H. Ehrenfeld, J. Elkins, M. Englert, S. Erlemeier, G. Eubank, P. Fayad, R. Felberg, W. Felton III, R. Ferguson, S. Flitman, P. Fonzetti, K. Furie, M. Garcia, G. Gardziola, J. Gebel, J. Glass, L. Goldstein, A. Goldszmidt, S. Goli, G. Graham, D. Graybeal, B. Grayum, E. Green, J. Green, P. Green, D. Greer, T. Gropen, J. Gross, J. Grotta, R. Gunwardane, B. Haake, T. Habiger, J. Halsey, D. Hanley, J. Hanna, C. Hansen, S. Hanson, G. Harpold, J. Harris, M. Harris, R. Hart, K. Hedges, B. Hendin, J. Hinchey, J. Ho, M. Hoffman, J. Hollander, W. Holt, K. Holzmacher, G. Howell, S. Howell, D. Huang, R. Hughes, R. Hull, T. Hwang, M. Jacobson, M. Jacoby, A. Jayam-Trouth, C. Jackson, K. John, B. Johnson-Finley, M. Johnson, S. Johnston, A. Kamal, P. Karanjia, C. Kase, S. Kasner, L. Katz, P. Katz, T. Kent, R. Kelley, C. Kidwell, A. Khanna, H. Kirshner, D. Kleindorfer, C. Knox, J. Kramer, L. Labiche, R. Lada, E.F. LaFranchise, M. LaMonte, M. Lee, P. Lee-Kwen, D. Leifer, E. Leira, K. Levin, R. Libman, D. Liebeskind, K. Lindholm, J.N. Livingstone II, G. Locke, W. Logan, J. Luciano, H. Lutsep, A. Majid, V. Mangeshkumar, S. Markind, L. Mate, J. McCain IV, W.A. McElveen, B. McKown, J. Merino, B. Meyer, T. Mikesell, T. Mirsen, L. Montoya, S. Moon, M. Moonis, K. Moore, J. Nasrallah, A. Nassief, M. Nelson, F. Nichols, J. Osborne, F. Oser, B. Ovbiagele, D. Palestrant, S. Panezai, N. Papamitsakis, G. Parry, M. Perez, C. Perkins, J. Porter, W. Preston, H. Rabiee, M. Raikhel, R. Reichwein, K. Remmel, B. Richardson, R. Ringel, D. Rosenbaum, D. Ross, M. Rubin, K. Ruffing, H. Sachdev, M. Sauter, J. Saver, J. Schafer, R. Schiftan, J. Schim, A.K. Schleining, M. Schneck, M. Selim, S. Sen, S. Shafer, B. Shafran, S. Sharfstein, D. Sherman, C. Sila, S. Silliman, B. Silver, B. Silverman, I. Silverman, R. Singh, N. Skillings, A. Slivka, D. Smith, R. Soto, S. Sparr, R. Stephens, H. Sullivan, G. Sung, J. Sutherland, A. Syed, M. Tabbaa, D. Tamulonis, R. Taylor, D. Tesfaye, T. Thomas, G. Tietjen, A. Todorov, M. Torbey, B. Tolge, M. Tremwell, W. Truax, D. Unwin, A. Vaishnav, N. Varma, Y.S. Venkatesh, P. Verro, R. Verson, T. Vidic, P. Vrooman, R. Wallis, D. Wang, J. Wang, M. Waters, L. Wechsler, J. Weinberger, J. Weissman, G. Wheatley, R. Whitehead, A. Willhite, H. Willis, E. Wilson, R. Wilson, J. Wilterdink, E. Wirkowski, M. Wozniak, C. Wright, M. Young, S. Zachariah, S. Zuckerman, R. Zweifler.

\section{REFERENCES}

1. Murray CJL, Lopez AD. Global mortality, disability, and the contribution of risk factors: Global Burden of Disease Study. Lancet 1997;349:1436-42.

2. Blood Pressure Lowering Treatment Trialists' Collaboration. Effects of different blood-pressure-lowering regimens on major cardiovascular events: results of prospectively-designed overviews of randomised trials. Lancet 2003;362:1527-35.

3. PROGRESS Collaborative Group. Randomised trial of a perindopril-based blood-pressure-lowering regimen among 6105 individuals with previous stroke or transient ischaemic attack. Lancet 2001; 358:1033-41. [Errata, Lancet 2001;358: 1556, 2002;359:2120.]

4. Lonn EM, Yusuf S, Jha P, et al. Emerg ing role of angiotensin-converting enzyme inhibitors in cardiac and vascular protection. Circulation 1994;90:2056-69. 5. Bosch JJ, Yusuf S, Pogue J, et al. Use of ramipril in preventing stroke: double blind randomised trial. BMJ 2002;324: 699-702.

6. The Heart Outcomes Prevention Evaluation Study Investigators. Effects of an angiotensin-converting-enzyme inhibitor, ramipril, on cardiovascular events in high-risk patients. N Engl J Med 2000; 342:145-53. [Errata, N Engl J Med 2000; 342:748, 1376.

7. Schrader J, Lüders S, Kulschewski A, et al. Morbidity and Mortality after Stroke, Eprosartan Compared with Nitrendipine for Secondary Prevention: principal results of a prospective randomized controlled study (MOSES). Stroke 2005;36: 1218-26.

8. Schrader J, Lüders S, Kulschewski A, et al. The ACCESS Study: evaluation of Acute Candesartan Cilexetil Therapy in Stroke Survivors. Stroke 2003;34:1699-703.

9. Diener HC, Sacco R, Yusuf S. Rationale, design and baseline data of a randomized, double-blind, controlled trial comparing two antithrombotic regimens (a fixed-dose combination of extendedrelease dipyridamole plus ASA with clopidogrel) and telmisartan versus placebo in patients with strokes: the Prevention Regimen for Effectively Avoiding Second Strokes trial (PRoFESS). Cerebrovasc Dis 2007;23:368-80. [Erratum, Cerebrovasc Dis 2008;25:192.]

10. Dahlöf B, Devereux RB, Kjeldsen SE, et al. Cardiovascular morbidity and mortality in the Losartan Intervention For Endpoint reduction in hypertension study (LIFE): a randomised trial against atenolol. Lancet 2002;359:995-1003.

11. The ACTIVE Steering Committee. Rationale and design of ACTIVE: the atrial fibrillation clopidogrel trial with irbesartan for prevention of vascular events. Am Heart J 2006;151:1187-93.

12. Teo K, Yusuf S, Sleight P, et al. Rationale, design and baseline characteristics of two large, simple randomized trials evaluating telmisartan, ramipril and their combination in high-risk patients: the Ongoing Telmisartan Alone and in Combination with Ramipril Global Endpoint Trial/Telmisartan Randomized Assessment Study in ACE Intolerant Subjects with Cardiovascular Disease (ONTARGET) TRANSCEND) trials. Am Heart J 2004; 148:52-61.

13. Yong M, Diener HC, Kaste M, Mau J. Characteristics of blood pressure profiles as predictors of long-term outcome after acute ischemic stroke. Stroke 2005;36: 2619-25.

14. Leonardi-Bee J, Bath PM, Phillips SJ, Sandercock PA, IST Collaborative Group. Blood pressure and clincial outcomes in the International Stroke Trial. Stroke 2002;33:1315-20.

15. Yusuf S, Gerstein H, Hoogwerf B, et al. Ramipril and the development of diabetes. JAMA 2001;286:1882-5.

16. Elliott WJ, Meyer PM. Incident diabetes in clinical trials of antihypertensive drugs: a network meta-analysis. Lancet 2007;369:201-7. [Erratum, Lancet 2007; 369:1518.]

17. The DREAM Trial Investigators. Effect of ramipril on the incidence of diabetes. N Engl J Med 2006;355:1551-62.

18. The ONTARGET Investigators. Telmisartan, ramipril, or both in patients at high risk for vascular events. $\mathrm{N}$ Engl J Med 2008;358:1547-59.

Copyright (c) 2008 Massachusetts Medical Society. 